\title{
Kebijakan PPDB Sistem Zonasi SMA/SMK dalam Mendorong Pemerataan Kulitas Sumberdaya Manusia di Jawa Timur
}

\author{
Ahmad Mashudi \\ Pascasarjana Universitas Airlangga Surabaya \\ Email: hudiahmad@gmail.com
}

\begin{abstract}
Abstrak
Tulisan ini mendiskusikan tentang pentingnya sistem zonasi dalam Penerimaan Peserta Didik Baru (PPDB) SMA/SMK terhadap pemerataan kualitas Sumberdaya Manusia (SDM) di Provinsi Jawa Timur. Sistem zonasi dalam penerimaaan siswa SMA/SMK akan menghindarkan penumpukan SDM dengan kualitas tertentu dalam wilayah. Zonasi penerimaan siswa SMA/SMK akan mendorong pemerataan SDM berkualitas di suatu wilayah, sehingga memudahkan pemenuhan kebutuhan tenaga kerja untuk menunjang kegiatan ekonomi setempat. Penulis menggunakan pendekatan kualitatif deskriptif dalam melakukan analisis tentang penerapan system zonasi dalam PPDB SMA/SMK di Jawa Timur. Strategi studi kasus kualitatif digunakan untuk menjelaskan dampak kebijakan tersebut dalam mengurangi kesenjangan kualitas SDM antarwilayah di Jawa Timur. Dalam hal ini, penulis menggunakan asumsi bahwa pemberian kesempatan yang sama untuk memperoleh pendidikan berkualitas di suatu wilayah akan menjamin ketersediaan SDM berkualitas secara merata. Tulisan ini mengemukakan hasil analisis yang menarik, bahwa kebijakan system zonasi PPDB tingkat SMA/SMK secara langsung maupun tidak langsung akan mendorong pemerataan SDM berkualitas di Jawa Timur. Pertama, kebijakan zonasi PPDB SMA/SMK menghindarkan adanya penumpukan calon siswa berkualitas tinggi hanya pada satu sekolah tertentu di wilayah tertentu, sehingga memunculkan ekslusivitas dalam bidang pendidikan. Kedua, penerapan kebijakan system zonasi menjamin ketersediaan tenaga kerja berkualitas secara merata, karena siswa memperoleh pengajaran oleh guru dan sumberdaya pendidikan dengan kualitas yang tidak berbeda. Tidak adanya kesenjangan kualitas lulusan tersebut pada akhirnya akan meningkatkan pemerataan kualitas SDM di semua wilayah Jawa Timur.
\end{abstract}

Kata kunci: PPDB Sistem Zonasi, SDM Berkualitas, Pemerataan

\begin{abstract}
This paper discusses the importance of the zoning system in the acceptance of SMA / SMK New Students (PPDB) towards the equal distribution of the quality of Human Resources (HR) in East Java Province. The zoning system in accepting high school / vocational students will prevent the accumulation of certain quality buman resources in the region. Zoning of high school / vocational student admissions will encourage equal distribution of quality buman resources in an area, making it easier to meet the needs of the workforce to support local economic activities. The author uses a descriptive qualitative approach in analyzing the application of zoning systems in PPDB SMA / SMK in East Java. A qualitative case study strategy was used to explain the impact of the policy in reducing disparity in human resource quality between regions in East Java. In this case, the authors use
\end{abstract}


the assumption that providing equal opportunities to obtain quality education in an area will guarantee the availability of quality buman resources equally. This paper presents an interesting analysis, that the direct or indirect PPDB zoning system policies at the SMA / SMK level will encourage even distribution of quality buman resources in East Java. First, the high school / vocational PPDB zoning policy avoids the accumulation of high-quality prospective students in only one particular school in a particular region, thus raising exclusivity in the field of education. Second, the implementation of the zoning system policy guarantees the availability of quality workforce equally, because students receive teaching by teachers and educational resources with no different quality. The absence of a gap in the quality of graduates will ultimately increase the even distribution of quality human resources in all regions of East Java.

Keywords: PPDB Zoning System, Qualified HR, Equity

\section{PENDAHULUAN}

Pemerataan kualitas sumberdaya manusia (SDM) masih menjadi persoalan di Jawa Timur. Ketersediaan SDM berkualitas antarwilayah tidak sama. SDM berkualitas cenderung menumpuk di suatu wilayah, terutama di kota-kota yang menjadi pusat aktivitas industry dan perdagangan. Selain factor urbanisasi, hal ini antara lain ditunjang oleh kesenjangan layanan pendidikan di Jawa Timur. Tidak semua calon peserta didiik memperoleh akses yang sama untuk memperoleh layanan pendidikan yang berkualitas. Akibatnya, lulusan dari layanan pendidikan berkualitas hanya dinikmati oleh orang di wilayah tertentu.

Berdasarkan data Badan Pusat Statistik (BPS) Jatim (Agustus 2017), jumlah penduduk usia kerja provinsi di Jawa Timur mencapai 30.443 .158 orang, dengan angkatan kerja berjumlah 20.937.716 orang, sementara yang bekerja baru 20.099.220 orang, sehingga jumlah pengangguran mencapai 838.496 orang. Namun, sebagian besar penduduk usia kerja terkonsentrasi di kota-kota besar dan pusta-pusat industri. Di Kota Surabaya terdapat 2.254.188 orang penduduk usia kerja, disusul Kabupaten Malang 1.989.403 orang, Kabupaten Jember 1.865.453 orang, kabupaten Sidoarjo 1.666.227 orang, Banyuwangi 1.244.401 orang, Kabupaten Pasuruan 1.230.104 orang, dan Kabupaten Gresik 973.800 orang. Sedangkan di kabupaten/kota lain, jumlah penduduk usia kerja jumlahnya lebh kecil, hanya di bawah 800 ribu orang.

Kesenjangan kualitas SDM juga terlihat dari tingkat pendidikan masyarakat. Jumlah penduduk usia kerja pada tingkat pendidikan dasar mencapai lebih dari 70 persen. Penduduk usia keja dengan hanya berpendidikan Sekolah Dasar mencapai 13.901.776 orang dan Sekolah Lanjutan Tingkat Pertama (SLTP) sebanyak 6.615.032 orang. Sedangkan lulusan SMTA umum 4.586.240 orang, SMTA Kejuruan 2.909.053 orang, D1-D3 sebanyak 439.496 orang, dan universitas sebanyak 1.991.291 orang. Jumlah penduduk yang bekerja menurut tingkat pendidikan di Jawa Timur pada 
tahun 2017 juga menumpuk pada tingkat pendidikan dasar, yakni Sekolah Dasar 9.508.632 orang dan SLTP 3.616.141 orang. Lulusan SMTA umum dan SMTA Kejuruan masing-masing 2.922.682 orang dan 2.088.937 orang.

Dalam bidang pendidikan, jumlah siswa SMA/SMK di Jawa Timur juga lebih terkonsentrasi di kota besar dan daerah industri. Data Pokok Pendidikan Dasar dan Menengah semester genap tahun 2018/2019 Kementerian Pendidikan menyebutkan, jumlah siswa SMA di Jawa Timur mencapai 533.268 orang dan SMK sebanyak 737.641 orang. Siswa SMA dan SMK di Kota Surabaya menjadi yang terbesar, yakni 60.533 orang dan SMK sebanyak 61.518 orang. Jumlah siswa SMA dan SMK di Kabupaten Sidoarjo menyusul di urutan kedua, yakni 33.630 orang dan 41.914 orang, Jember 25.495 orang dan 45.901 orang. Di kabupaten/kota ini, prosentase siswa yang melanjutkan pendidikan dari SD hingga SMA/SMK masih cukup besar. Sedangkan di luar kabupaten/kota tersebut, prosentase siswa yang melanjutkan ke jenjang lebih tinggi menurun drastic, sehingga sebagian besar hanya mengenyam pendidikan SD dan SLTP. Jumlah siswa SD di Kabupaten Tulungagung sebanyak 77.836 orang, namun data siswa SLTP hanya tinggal 36.739 orang dan Kabupaten Bojonegoro siswa SD sebanyak 78.141 orang dan SLTP sebanyak 36.739 orang.
Penyebaran SDM berkualitas yang tidak merata dapat mengganggu pertumbuhan ekonomi suatu wilayah, karena aktivitas ekonomi tidak berjalan secara optimal. Hal ini dibuktikan dengan stagnasi pertumbuhan ekonomi Jawa Timur selama tiga tahun terakhir, yakni hanya tumbuh antara 5,5 5,8 persen. Walaupun masih di atas rata-rata nasional, pertumbuhan ekonomi Jawa Timur mengalami stagnasi berkepanjangan. Salah satu penyebabnya adalah sumbangan industri pengolahan yang relative rendah pada Produk Domestik Regional Bruto (PDRB). Sumbangan industri pengolahan hanya 29, 70 persen pada tahun 2018. Itu pun didominasi oleh pelakju industri kecil dan menengah. Sedangkan industri pengolahan kategori besar justru mengurangi tenaga kerjanya karena melakukan relokasi ke provinsi lain atau bahkan ke luar negeri.

Penurunan kontribusi dan peran sektor manufaktur dalam system ekonomi suatu wilayah menjadi ancaman serius pada masa yang akan datang. Menteri Perencanaan Pembangunan/Kepala Bappenas Sumantri PS Brodjonegoro mengatakan, industrialisasi menjadi suatu keharusan bagi Indonesia agar dapat menyediakan lapangan kerja berkualitas, meningkatkan produktivitas ekonomi, yang pada akhirnya dapat mendongkrak pertumbuhan ekonomi potensial jangka menangah dan panjang. Apalagi, proses industrialisasi ini nantinya 
akan diiringi oleh proporsi penduduk usia muda dan kelas menengah yang meningkat. ${ }^{1}$

Untuk mendorong peningkatan sumbangan industri pengolahan, Pemerintah Provinsi Jawa Timur mendorong pengembangan industri kecil dan menengah berbasis agro dan non agro, serta pengembangan kawasan industry di Banyuwangi, Probolinggo, Jombang, Nganjuk, Tuban, Lamongan, dan Madiun sebagai upaya mengoptimalkan jaringan tol Transjava yang sudah tersambung dari Ngawi hingga Probolinggo. Jumlah penduduk yang bekerja pada setiap kategori lapangan pekerjaan menunjukkan kemampuan dalam penyerapan tenaga kerja. Menurut data BPS Jawa Timur, per Februari 2019, struktur penduduk bekerja menurut lapangan pekerjaan masih didominasi oleh tiga lapangan pekerjaan utama, yaitu pertanian sebesar 32,15 persen, perdagangan 17,73 persen, dan industri pengolahan sebesar 15,93 persen.

Industri pengolahan di Jawa Timur didominasi industri kecil. Dari 812.678 unit usaha industri di Jatim, 97,39 persen atau 791.442 unit termasuk dalam industri kecil. Sedangkan industri menengah hanya 2,47 persen atau 20.091 unit dan industri besar 0,14 persen atau 1.145 unit. Namun, industri kecil menjadi andalan menyerap tenaga

1 Bambang PS Brodjonegoro, Keharusan Transformasi Industri, (Harian Kompas, 3 Juli 2019) hal : 6 . kerja, dengan penyerapan 1.824 .369 atau 57,73 persen total tenaga kerja di Jatim. Sedangkan industri besar hanya menyerap 11,77 persen. Sisanya terserap di industri menengah. ${ }^{2}$

Menurut Bambang PS Brodjonegoro, rendahnya inovasi, kualitas investasi dan hambatan domestik menjadi akar dari permasalahan pengembangan dan transformasi industri pengolahan. Kondisi birokrasi yang masih berbiaya tinggi serta kurangnya infrastruktur dan SDM berkualitas juga turut berkontribusi atas permasalahan sektor industri nasional.

Faktor kurangnya SDM berkualitas merupakan tantangan tersendiri dalam penegembangan industri di Jawa Timur. Saat ini, upaya pemerataan kesempatan memperoleh pendidikan terus dilakukan oleh Pemerintah Provinsi Jawa Timur. Anak usia sekolah memperoleh kemudahan dan kesempatan yang sama untuk mendapatkan pendidikan, dengan program Pendidikan Gratis Berkualitas (Tistas) yang dicanangkan Gubernur Jatim Khofifah Indar Parawansa.

Upaya pengembangan SDM juga dilakukan dengan memperbanyak sekolah kejuruan atau pendidikan vokasi. Gedung SMK didirikan untuk menyongsong era industri di semua wilayah. Hasilnya proporsi siswa sekolah kejuruan meningkat tajam di Jawa Timur, dari 40:60 menjadi

2 Saifullah Yusuf, Industri yang Menyejabterakan, (www.detik.com, tanggal 12 juli 2017). 
kebalikannya. Jumlah siswa SMK pada semester genap tahun 2018/2019 mencapai 737.641 orang atau jauh di atas siswa SMA sebanyak 533.268 orang. Pelatihan bagi pencari kerja dan sertifikasi kompetensi tenaga kerja juga dilakukan, baik melalui Balai Latihan Kerja (BLK) milik pemerintah maupun Lembaga Pelatihan Kerja Swasta (LPKS).

Namun, upaya pemerataan kualitas SDM yang dilakukan Pemerintah Provinsi Jawa Timur belum memberikan hasil siginifikan. Penelitian yang dilakukan Dwi Eko Waluyo dan Setyo Wahyu Sulistyono di di Kecamatan Selorejo Kabupaten Blitar Provinsi Jawa Timur menunjukkan bahwa faktor pendidikan menjadi salah satu faktor pendorong seorang menjadi Tenaga Kerja Indonesia (TKI) ke luar negeri. Oleh karena itu, mereka berkesimpulan bahwa pendidikan seharusnya menjadi pertimbangan dalam perencanaan tenaga kerja baik nasional maupun daerah yang tepat, yang akan dapat memperkirakan kebutuhan tenaga kerja untuk daerah tertentu, sektor tertentu, pada waktu tertentu untuk keahlian tertentu dan atau juga sebaliknya. Secara umum terjadinya pengangguran merupakan akibat dari masalah pasar kerja, tenaga kerja, dan kesempatan kerja dan selanjutnya diperlukan sinergi antara permintaan dan penawaran tenaga kerja yang diwadahi oleh perencanaan tenaga kerja nasional maupun daerah. ${ }^{3}$

Selain meningkatkan kualitas kompetensi, pemerintah juga mendorong pemerataan SDM berdasarkan kewilayahan. Salah satunya dengan mengeluarkan kebijakan Penerimaan Peserta Didik Baru (PPDB) dengan system zonasi di tingkat SMA/SMK. Berdasarkan Permendikbud Nomor 51 Tahun 2018 tentang Penerimaan Peserta Didik Baru (PPDB) pada Taman Kanak-kanak, Sekolah Dasar, Sekolah Menengah Pertama, Sekolah Menengah Atas dan Sekolah Menengah Kejuruan, sekolah wajib menerima calon siswa dengan kuota 90 persen melalui jalur zonasi. Zonasi calon siswa ditentukan oleh pemerintah daerah mainig-masing dengan menetapkan alamat Kartu Keluarga yang sudah dibuat minimal 1 (satu) tahun sebelumnya. Sedangkan, untuk jalur prestasi dan perpindahan orang tua diberikan kuota masing-masing 5 persen.

Menteri Pendidikan dan Kebudayaan Muhadjir Effendy menyebutkan, negara maju yang telah lebih dulu menerapkan sistem zonasi yakni Jepang. Menurutnya, Jepang merupakan negara dengan sistem pendidikan zonasi terbaik, meski dalam proses pemerataan zonasi Jepang membutuhkan waktu sekitar 30 tahun. Hal

${ }^{3}$ Eko Waluyo dan Setyo Wahyu Sulistyono, Faktor Pendorong Keberangkatan TKI dalam Memenubi Investasi Non Fisik di Kecamatan Selorejo Kabupaten Blitar, Jurnal Inovasi Ekonomi Vol. 03 No.01 Maret 2018 hal : 1-9. 
itu menjadikan kualitas pendidikan Jepang saat ini bagus dan merata. ${ }^{4}$

Landasan sosiologis yang mendasari penerapan kebijakan zonasi diantaranya adalah adanya fakta ketimpangan atau kesenjangan pendidikan antardaerah. Kemudian belum meratanya kualitas dan kuantitas sekolah, khususnya dalam sarana prasarana dan guru. Dan diskriminasi dan ketidakadilan terhadap akses dan layanan pendidikan sebagai layanan dasar yang wajib diberikan kepada semua warga negara. "Sekolah negeri yang relatif murah lebih banyak dinikmati oleh anak dari keluarga mampu. Sementara banyak anak dari keluarga tidak mampu terancam putus sekolah. Angka putus sekolah kita masih cukup tinggi, ini tidak boleh dibiarkan terus menerus,"jelas Chatarina Muliana Girsang, Staf Ahli Menteri Pendidikan dan Kebudayaan (Staf Ahli Mendikbud) bidang Regulasi. ${ }^{5}$

Namun kenyataannya pelaksanaan PPDB system zonasi memunculkan respons yang beragam. Berbagai protes berdatangan, di antaranya di Kota Surabaya. Sebagian orang tua memprotes kecilnya porsi jalur prestasi, yang hanya 5 persen. Mereka

${ }^{4}$ Biro Komunikasi dan Layanan Masyarakat Kementerian Pendidikan dan Kebudayaan, Mendikbud: Zonasi Bukan Hanya Untuk PPDB Saja (https://www.kemdikbud.go.id tanggal 18 juni 2019)

5 Biro Komunikasi dan Layanan Masyarakat Kementerian Pendidikan dan Kebudayaan, Didukung DPR dan Ombudsman, Sistem Zonasi Pendidikan Segera Diatur Perpres (https://www.kemdikbud.go.id tanggal 2 Juli 2019). berpendapat kebijakan ini justru tidak adil, karena sekolah mengutamakan siswa dari zonasi yang ditentukan, dan tidak menghargai upaya siswa untuk berprestasi dan memperoleh pendidikan di sekolah yang mereka inginkan.

Protes tidak hanya terjadi di Kota Surabaya, namun terjadi di berbagai wilayah Indonesia. Pemerintah kemudian mengeluarkan revisi PPDB system zonasi dengan mengeluarkan Permendikbud No 20 tahun 2019 tentang Perubahan Permendikbud Nomer 51 tahun 2018. Pemerintah melonggarkan kuota jalur prestasi menjadi 5 hingga 15 persen dari pagu siswa yang diterima di suatu sekolah.

Anggota Ombudsman Ninik Rahayu mengatakan, Permendikbud Nomer 51 tahun 2018 tidak berjalan optimal karena kurang sosialisasi kepada masyarakat. "Seharusnya waktu enam bulan dapat digunakan untuk persiapan dan sosialisasi kepada masyarakat tentang pelaksanaan PPDB dan perbedaan dengan tahun-tahun sebelumnya sehingga tidak menimbulkan keributan mendadak,"ujar Ninik Rahayu. ${ }^{6}$

Tulisan ini akan mendiskusikan peranan dampak kebijakan PPDB system zonasi di SMA/SMK terhadap pemerataan kualitas SDM di Jawa Timur, yang dianalisis dengan menggunakan pendekatan manajemen

\footnotetext{
${ }^{6}$ Christoforus Ristianto, Soal PPDB, Ombudsman Menilai Kemendikbud Kurang Koordinasi dengan Kemendagri (https://nasional.kompas.com tanggal 27 Juni 2019)
} 
pendidikan dan perencanaan tenaga kerja daerah di Jawa Timur, yang dipadu dengan teori-teori lainnya dalam memahami persoalan sosial di balik penolakan sejumlah orangtua siswa terhadap kebijakan tersebut. Hasil dari penelitian ini diharapkan akan memeberikan sumbangan pemikiran dalam pembangunan SDM dan pemerataan tenaga kerja berkualitas, untuk mendukung pembangunan ekonomi dan pengembangan industri pengolahan di Jawa Timur, dan Indonesia pada umumnya.

\section{KAJIAN TEORI}

Pembangunan sumber daya manusia sebagai rangkaian upaya untuk mewujudkan manusia seutuhnya dan masyarakat mencakup pembangunan manusia, baik sebagai insan maupun sebagai sumber daya pembangunan, yang merupakan satu kesatuan yang tidak terpisahkan ${ }^{7}$. Manusia sebagai insan menjadi perhatian utama dalam peningkatan kualitas sumber daya manusia karena menjadi dasar dari kehidupan dirinya. Keberhasilan membangun manusia sebagai insan seutuhnya akan menentukan keberhasilan membangun manusia pada sisi lainnya, yakni pelaku yang tangguh dalam membangun diri dan lingkungannya. Pengetahuan, keterampilan, dan keahlian

7 Imam Mawardi, 'Pendidikan Islam Transdisipliner Dan Sumber Daya Manusia Indonesia', Jurnal Pendidikan Islam 28, no. 2 (2016): 253-268. harus ditegakkan di atas dasar etika moral dan akhlak yang baik. Pembangunan manusia sebagai sumber daya pembangunan menekankan manusia sebagai pelaku pembangunan yang memiliki etos kerja produktif, keterampilan, kreativitas, disiplin, profesiona-lisme, serta memiliki kemampuan memanfaatkan, mengembangkan, dan menguasai ilmu pengetahuan dan teknologi (iptek) yang berwawasan lingkungan maupun kemampuan manajemen. Kualitas manusia sebagai insan dan sumber daya pembangunan seperti itu akan membawa Indonesia tumbuh dan maju menjadi bangsa besar yang sejajar dengan bangsa maju lainnya ${ }^{8}$.

Sebagai sebuah organisasi, Pemerintah Provinsi Jawa Timur harus menentukan masa depannya dengan berbagai rencana yang relevan dengan tuntutan jaman. Pada era seperti sekarang ini, masa depan sangat sukar diprediksi karena perubahan yang terjadi sangat cepat. Organisasi dituntut untuk terus bergerak mengikuti arus perubahan yang sangat cepat dan massif. Dalam konteks ini, perencanaan SDM menjadi lebih penting karena globalisasi, teknologi baru, dan proses restrukturisasi organisasi selalu membayangi kehidupan organisasi, termasuk pemerintah. Agar

8 Hefni Zain, 'Pengembangan Pendidikan Islam Multikultural Berbasis Manajemen Sumber Daya Manusia', Tadris: Jurnal Pendidikan Islam 8, no. 1 (2014): 108-124; Meldona, Manajemen Sumber Daya Manusia: Perspektif Integratif, Cetakan I (Malang: UINMalang Press, 2009). 
dalam pelaksanaan perencanaan SDM bisa berhasil, sedikitnya terdapat empat aspek perencanaan SDM yang harus diperhatikan/dilakukan yaitu: (1) berapa proyeksi jumlah tenaga kerja yang dibutuhkan (forecasting of employees), (2) melakukan identifikasi SDM yang tersedia dalam organisasi (buman resource audit), (3) melakukan analisis keseimbangan penawaran dan permintaan (demand and suplay analysis), (4) menjalankan program aksi (action program). Menurut Dessler yang dikutip oleh Kristiawan manajemen sumber daya manusia adalah kebijakan dan praktik menentukan aspek "manusia" atau sumber daya manusia dalam posisi manajemen, termasuk merekrut, menyaring, melatih, memberi penghargaan dan penilaian?

Persediaan tenaga kerja di suatu wilayah merupakan salah satu komponen vital dalam proses pembangunan di wilayah tersebut. Pada aspek perencanaan, persediaan tenaga kerja salah satunya meliputi perkiraan ketersediaan tenaga kerja baru, terutama jumlah lulusan SMA/SMK/Perguruan Tinggi yang nantinya akan memasuki pasar kerja. Secara subtansi, perkiraan itu meliputi perkiraan Penduduk Usia Kerja (PUK), perkiraan Tingkat Partisipasi Angkatan

9 Muhammad Kristiawan, 'Telaah Revolusi Mental Dan Pendidikan Karakter Dalam Pembentukkan Sumber Daya Manusia Indonesia Yang Pandai Dan Berakhlak Mulia', Ta'dib 18, no. 1 (2016): 13-25.
Kerja (TPAK), dan perkiraan angkatan kerja dengan berbagai karakteristik.

Sesungguhnya di Indonesia, secara konseptual pembangunan pendidikan tampaknya ditautkan secara erat dengan pembangunan ekonomi. Di dalam Undangundang No. 25 tahun 2000 tentang Program Pembangunan Nasional, pembangunan pendidikan tidak hanya dikaitkan secara erat dengan pembangunan ekonomi, melainkan juga dengan tantangan globalisasi. Disebutkan disini bahwa pada awal abad XXI, dunia pendidikan di Indonesia menghadapi tiga tantangan besar. Pertama, sebagai akibat krisis ekonomi, dunia pendidikan dituntut untuk mempertahankan hasil-hasil pembangunan pendidikan yang telah dicapai. Kedua, untuk mengantisipasi era globalisasi, dunia pendidikan dituntut untuk mempersiapkan sumberdaya manusia yang kompeten agar mampu bersaing dalam pasar kerja global. Ketiga, sejalan dengan diberlakukannya otonomi daerah, sistem pendidikan nasional dituntut untuk melakukan perubahan dan penyesuaian sehingga dapat mewujudkan proses pendidikan yang demokratis, memperhatikan keberagaman kebutuhan/keadaan daerah dan peserta didik, serta mendorong peningkatan partisipasi masyarakat.

Sedangkan pemerataan pendidikan berkenaan dengan seberapa luas pendidikan telah menjangkau seluruh warga negara. 
Mutu pendidikan berkenaan dengan seberapa mendalam pendidikan telah memberikan nilai tambah pada para peserta didik. Sedangkan manajemen berkenaan dengan pengelolaan institusi pendidikan sehingga mencapai tujuan kelembagaan. Indikator pemerataan pendidikan dapat dilihat dari jumlah sekolah perpenduduk usia sekolah, jumlah guru, jumlah siswa persekolah, jumlah putus sekolah serta jumlah buta huruf ${ }^{10}$. Menurut studi Coleman dalam bukunya Equality of Educational Opportunity secara konsepsional konsep pemerataan yaitu pemerataan aktif dan pemerataan pasif. Pemerataan pasif adalah pemerataan yang lebih menekankan pada kesamaan memperoleh kesempatan untuk mendaftar di sekolah, sedangkan pemerataan aktif bermakna kesamaan dalam memberi kesempatan kepada murid-murid terdaftar agar memperoleh hasil belajar setinggitingginya ${ }^{11}$.

Tujuan manajemen peserta didik menurut Sururi \& Nasihin adalah mengatur kegiatan-kegiatan peserta didik agar kegiatan-kegiatan tersebut menunjang proses pembelajaran di lembaga pendidikan, lebih lanjut proses pembelajaran di sekolah dapat berjalan lancar, tertib dan teratur sehingga dapat memberikan kontribusi bagi

10 Puspo Nugroho, 'Internalization of Tolerance Values in Islamic Education', Nadwa 12, no. 2 (7 January 2019): 197-228, https://doi.org/10.21580/nw.2018.12.2.2397.

${ }^{11}$ H.A.R Tilaar, Perubahan sosial dan pendidikan: pengantar pedagogik transformatif untuk. Indonesia (Jakarta: Rineka Cipta, 2012). pencapaian tujuan sekolah dan tujuan pendidikan secara keseluruhan.

Fungsi manajemen peserta didik menurut Imron adalah sebagai berikut ${ }^{12}$ : Pertama, fungsi yang berkenaan dengan pengembangan individualitas peserta didik, ialah agar mereka dapat mengembangkan potensi-potensi individualitasnya tanpa banyak terhambat. Potensi-potensi bawaan tersebut meliputi kemampuan umum (kecerdasan), kemampuan khusus (bakat), dan kemampuan lainnya. Kedua, fungsi yang berkenaan dengan pengembangan fungsi sosial peserta didik ialah agar peserta didik dapat mengadakan sosialisasi dengan sebayanya, dengan orang tua dan keluarganya, dengan lingkungan sosial sekolahnya dan lingkungan sosial masyarakatnya. Fungsi ini berkaitan dengan hakekat peserta didik sebagai makhluk sosial. Ketiga, fungsi yang berkenaan dengan penyaluran aspirasi dan harapan dengan peserta didik, ialah agar peserta didik tersalur hobi, kesenangan dan minatnya. Hobi, kesenangan dan minat peserta didik demikian dapat disalurkan, oleh karena ia juga dapat menunjang terhadap perkembangan diri peserta didik secara keseluruhan. Keempat, fungsi yang berkenaan dengan pemenuhan kebutuhan dan kesejahteraan peserta didik ialah agar peserta didik sejahtera hidupnya. Kesejahteraan akan melahirkan kesejahteraan sebayanya.

12 Meldona, Manajemen Sumber Daya Manusia. 
Ada beberapa prinsip yang perlu diperhatikan agar tujuan dan fungsi manajemen peserta didik dapat tercapai. Sururi \& Nasihin menjelaskan prinsipprinsip yang dimaksud adalah: (1) dalam mengembangkan program manajemen kepesertadidikkan, penyelenggara harus mengacu pada peraturan yang berlaku pada saat program dilaksanakan; (2) manajemen peserta didik dipandang sebagai bagian keseluruhan manajemen sekolah, oleh karena itu ia harus mempunyai tujuan yang sama dan atau mendukung terhadap tujuan manajemen sekolah secara keseluruhan; (3) segala bentuk kegiatan manajemen peserta didik haruslah mengemban misi pendidikan dan dalam rangka mendidik peserta didik; (4) kegiatan-kegiatan manajemen peserta didik haruslah diupayakan untuk mempersatukan peserta didik yang mempunyai keragaman latar belakang dan punya banyak perbedaaan. Perbedaanperbedaan yang ada pada peserta didik tidak diarahkan bagi munculnya konflik diantara mereka melainkan justru untuk mempersatukan, saling memahami dan saling menghargai. Sehingga setiap peserta didik memiliki wahana untuk berkembang secara optimal; (5) kegiatan manajemen peserta didik haruslah dipandang sebagai upaya pengaturan terhadap pembimbingan peserta didik; (6) kegiatan manajemen peserta didik haruslah mendorong dan memacu kemandirian peserta didik. prinsip kemandirian akan bermanfaat tidak hanya ketika di sekolah, melainkan juga ketika sudah terjun ke masyarakat; dan (7) kegiatan manajemen peserta didik haruslah fungsional bagi kehidupan peserta didik, baik di sekolah lebih-lebih di masa depan.

Manajemen peserta didik SMA/SMA menyiapkan lulusan untuk menjadi anggota masyarakat. Pendidikan sekolah menengah diselenggarakan untuk melanjutkan dan meluaskan pendidikan dasar serta menyiapkan peserta didik yang memiliki kemampuan mengadakan hubungan timbal balik dengan lingkungan sosial, budaya dan alam sekitar serta dapat mengembangkan kemampuan lebih lanjut dalam dunia kerja atau pendidikan tinggi.

Menurut Undang-Undang Nomor 20 Tahun 2003 Tentang Sistem Pendidikan Nasional jenis pendidikan sekolah menengah ada dua yaitu: pendidikan menengah umum dan pendidikan menengah kejuruan. Pendidikan sekolah menengah umum diselenggarakan oleh Sekolah Menengah Atas (SMA) yang dulunya disebut sebagai Sekolah Menengah Umum (SMU) atau Madrasah Aliyah (MA). Pendidikan menengah umum dapat dikelompokkan dalam program studi sesuai dengan kebutuhan untuk belajar lebih lanjut di perguruan tinggi dan hidup di dalam masyarakat. Sedangkan pendidikan menengah kejuruan diselenggarakan oleh Sekolah Menengah Kejuruan (SMK) atau 
Madrasah Aliyah Kejuruan (MAK).

Pendidikan menengah kejuruan

dikelompokkan dalam bidang kejuruan

didasarkan pada perkembangan ilmu

pengetahuan, teknologi, dan/atau seni,

dunia industri/dunia usaha, ketenagakerjaan

baik secara nasional, regional maupun global, kecuali untuk program kejuruan yang terkait dengan upaya-upaya pelestarian warisan budaya ${ }^{13}$.

Namun pelaksanaan kebijakan seringkali mengahadapi hambatan, karena respons masyarakat yang beragam. Hal ini terjadi karena struktur social masyarakat yang berbeda-beda. Pendekatan struktural fungsional sebagaimana yang dikembangkan oleh Talcot Parson didasarkan pada pendekatan integrasi dan dapat dilihat dari anggapan dasar yang dikemukakannya. Pertama, masyarakat harus dilihat sebagai suatu sistem dari pada bagian-bagian yang saling berhubungan satu sama lain. Kedua, hubungan saling mempengaruhi diantara bagian tersebut bersifat ganda dan timbal balik. Ketiga, sekalipun interaksi sosial tidak akan pernah tercapai dengan sempurna, namun secara fundamental bergerak kearah

13 Muhammad Anas Maarif, 'Optimalisasi Pembelajaran Pendidikan Islam Di Sekolah/Madrasah Upaya Dan Faktor Penghambat Pembelajaran Pendidikan Islam', Falasifa: Jurnal Studi Keislaman 8, no. 2 (2018): 273-290; Nata Abudin, Managemen Pendidikan: Mengatasi Kelemahan Pendidikan di Indonesia (Jakarta: Prenada Media Grup, 2003); Sudarsri Lestari, 'Analisis Standar Pendidik Dan Tenaga Kependidikan (Studi Di Sdn 3 Tamanagung Banyuwangi)', Nidhomul Haq: Jurnal Manajemen Pendidikan Islam 3, no. 1 (16 August 2018): 18-22, https://doi.org/10.31538/ndh.v3i1.35. equilibrium yang bersifat dinamis. Keempat, sekalipun disfungsi, ketegangan, dan penyimpangan-penyimpangan senantiasa terjadi juga, akan tetapi pada jangka panjang, akhirnya akan teratasi dengan sendirinya melalui penyesuaian-penyesuaian dan proses institusionalisasi. Kelima, perubahanperubahan dalam sistem sosial pada umumnya akan terjadi secara gradual, melalui penyesuaian dan tidak terjadi secara revolusioner. Keenam, perubahan-perubahan yang terjadi melalui tiga macam kemungkinan, yaitu penyesuaianpenyesuaian yang dilakukan oleh sistem sosial tersebut terhadap perubahanperubahan yang datang dari luar, perubahan melalui diferensiasi struktur fungsional, serta penemuan baru oleh masyarakat. Ketujuh, faktor terpenting yang memiliki daya mengintegrasi suatu sistem social adalah konsensus diantara anggota-anggotanya mengenai nilai kemasyarakatan tertentu ${ }^{14}$.

Kehidupan manusia tidak terpikirkan di luar masyarakat. Individu-individu tak bisa hidup dalam keterpencilan sama sekali selama-lamanya. Manusia membutuhkan satu sama lain untuk bertahan hidup dan hidup sebagai manusia. Kesaling ketergantungan ini menghasilkan bentuk kerja sama tertentu yang bersifat ajek, dan menghasilkan bentuk masyarakat tertentu,

14 Abdallah Abdallah, 'Exclusivism and Radicalism in Schools: State Policy and Educational Politics Revisited', Studia Islamika 23, no. 3 (30 December 2016): 625-32, https://doi.org/10.15408/sdi.v23i3.4425. 
sebuah keniscayan. Manusia adalah mahluk sosial. Itu hampir tidak dapat diragukan.

\section{METODE PENELITIAN}

Rancangan penelitian dalam penelitian ini menggunakan metode eskriptif evaluatif. Deskriptif evaluatif pada dasarnya adalah untuk menjelaskan adanya kegiatan penelitian yang sifatnya mengevaluasi terhadap sesuatu objek, yang biasanya merupakan pelaksanaan dan rencana Depdiknas, . Jadi yang dimaksud dengan penelitian evaluasi adalah penelitian yang bertujuan untuk mengumpulkan informasi tentang apa yang terjadi, yang merupakan kondisi nyata mengenai keterlaksanaan rencana yang memerlukan evaluasi. Melakukan evaluasi berarti ingin mengetahui apakah implementasi program yang telah direncanakan sudah berjalan dengan benar dan sekaligus memberikan hasil yang sesuai. Tujuan penelitian ini mengacu kepada pendapat Patton ${ }^{15}$ yaitu untuk menginformasikan tindakan, membantu pengambilan keputusan, dan menerapkan ilmu pengetahuan untuk memecahkan permasalahan kemanusiaan dan kemasyarakatan.

Dalam penelitian ini digunakan teknik analisis kualitatif dengan metode deskriptif. Analisis kualitatif yang dilakukan

15 Michael Quinn Patton and Michael Quinn Patton, Qualitative Research and Evaluation Methods, 3 ed (Thousand Oaks, Calif: Sage Publications, 2002), 16. dalam penelitian ini disesuaikan dengan definisi dari penelitian kualitatif menurut Kirk dan Miller dalam Moleong ${ }^{16}$ yaitu tradisi tertentu dalam ilmu pengetahuan sosial yang secara fundamental bergantung pada manusia dalam kawasannya sendiri dan berhubungan dengan orang-orang tersebut dalam bahasanya dan dalam peristilahannya. Oleh karena itu dalam penelitian kualitatif sangat diperlukan tindakan serta kata-kata yang diambil dari hasil wawancara dan observasi di lapangan. Sedangkan untuk data tambahan dapat dipergunakan dokumentasi dan sumber tertulis seperti : majalah ilmiah, sumber arsip dan dokumen pribadi maupun resmi. Metode deskriptif digunakan untuk memperoleh gambaran suatu keadaan yang sedang berlangsung ${ }^{17}$. Metode ini dilakukan dengan menempuh langkah-langkah pengumpulan data, klasifikasi, analisis data, dan membuat kesimpulan dengan tujuan utama untuk membuat penggambaran tentang suatu keadaan secara nyata dan obyektif $^{18}$.

Subjek penelitian tidak selalu berupa orang, tetapi dapat berupa benda,kegiatan, tempat ${ }^{19}$. Penelitian ini mengevaluasi

16 Moloeng Lexy J, Metodologi penelitian Kualitatif, 29th ed. (Bandung: Rosdakarya, 2011).

17 John W. Creswell, Qualitative Inquiry \& Research Design: Choosing among Five Approaches, 2nd ed (Thousand Oaks: Sage Publications, 2007).

18 John W. Creswell, Educational Research: Planning, Conducting, and Evaluating Quantitative and Qualitative Research, 4th ed (Boston: Pearson, 2012).

19 Arikunto Suharsimi, Metode Penelitian Pendidikan dan Pengembangan, 5th ed. Jakarta: Kencana, 2016). 
kebijakan pemerintah dalam menetapkan pelaksanaan PPDB dengan system zonasi SMA/SMK dan manfaatnya dalam pemerataan SDM berkualitas di Jawa Timur. Permasalahan yang menjadi bahasan adalah pelaksanaan PPDB sistem zonasi, perencanaan tenaga kerja, dan pemerataan kualitas SDM di Jawa Timur.

Pengumpulan data dan informasi dilakukan dengan metode observasi dan studi dokumentasi. Observasi merupakan metode pengumpulan data yang digunakan pada penelitian yang berkenaan dengan perilaku manusia, proses kerja, gejala-gejala alam dan untuk jumlah responden yang tidak terlalu besar ${ }^{20}$. Metode observasi digunakan karena penelitian ini ingin melihat perilaku manusia dalam merespons kebijakan PPDB system zonasi dan proses manajemen perencanaan tenaga kerja di Jawa Timur.

Data yang berhasil dikumpulkan dari lokasi penelitian, selanjutnya dianalisa dan kemudian disajikan secara tertulis dalam laporan, yaitu berupa data yang ditemukan dari observasi partisipan, studi dokumentasi dan wawancara dengan berbagai sumber. Adapun langkah-langkah yang diterapkan peneliti dalam menganalisa data yaitu mengikuti alur yang dinyatakan oleh Miles

20 Sugiyono, Metode penelitian pendidikan: (pendekatan kuantitatif, kualitatif dan R \& D) (Bandung: Alfabeta, 2008). dan Huberman ${ }^{21}$ bahwa analisis data terdiri dari tiga alur kegiatan yang terjadi secara bersamaan yaitu reduksi data, paparan/penyajian data dan penarikan kesimpulan yang dilakukan selama dan sesudah penelitian.

\section{PPDB ZONASI DAN PEMERATAAN PENDIDIKAN}

Penerimaan peserta didik baru merupakan salah satu program kegiatan sekolah dan termasuk dalam perencanaan peserta didik dalam lingkup manajemen peserta didik. Kebijakan zonasi yang diterapkan sejak tahun 2016 menjadi pendekatan baru yang dipilih pemerintah untuk mewujudkan pemerataan akses pada layanan dan kualitas pendidikan di seluruh Indonesia. Menteri Pendidikan dan Kebudayaan Muhadjir Effendy menegaskan bahwa PPDB system zonasi untuk memberikan akses yang setara dan adil kepada semua peserta didik tanpa melihat kemampuan (prestasi) dan perbedaan status sosial ekonomi. "Prestasi itu tidak diukur dari asal sekolah, tetapi masing-masing individu anak yang akan menentukan prestasi dan masa depannya. Pada dasarnya setiap anak itu punya keistimewaan dan keunikannya sendiri. Dan kalau itu dikembangkan secara baik itu akan menjadi modal untuk masa depan," ujarnya.

21 Matthew B. Miles, A. M. Huberman, and Johnny Saldaña, Qualitative Data Analysis: A Methods Sourcebook, Third edition (Thousand Oaks, Califorinia: SAGE Publications, Inc, 2014). 
Perimaan peserta didik baru tingkat SMA/SMK di Jawa Timur untuk kategori zonasi atau reguler dibuka Senin (17/6/2019) pukul 00.00 WIB. Pendaftaran akan berlangsung sampai Jumat, 21 Juni 2019. Pada tanggal 27 Mei-20 Juni 2019, calon peserta didik mengambil PIN/Tes kesehatan pada SMA atau SMK Negeri yang dituju. Calon peserta mendaftarkan dirinya secara online melalui website https://ppdbjatim.net/. Dalam laman PPDB on line di Jatim ini, panitia menetapkan sejumlah persyaratan, di antaranya : calon peserta didik baru harus mempertimbangkan zona tempat tinggal dengan sekolah tujuan, calon peserta didik baru hanya diizinkan mendaftar sekali, dan setelah terdaftar tidak dapat mencabut kembali untuk setiap jalur pendaftarannya, calon peserta didik baru harus memiliki PIN yang dapat diambil di SMA/SMK Negeri terdekat dan calon peserta didik baru hanya dapat memilih 1 (satu) satuan pendidikan tujuan saja yaitu SMA atau SMK.

Hasil dari jalur pendaftaran zonasi/reguler diumumkan secara online pada 21 Juni 2019 pukul 01.00 WIB. Peserta didik baru yang telah diterima melakukan pendaftaran ulang pada 21-22 Juni 2019 pukul 08.00 sampai 15.00 WIB di sekolah yang diterima masing-masing. PPDB system zonasi ini diselenggarakan setelah pendaftaran jalur prestasi, perpindahan tugas orangtua, Inklusi, dan
Keluarga Tidak Mampu yang telah dilakukan secara offline pada tanggal 11-13 Juni 2019 pada pukul 08.00-14.00 WIB yang telah melewati tahap vertifikasi dan validasi data pada 14-15 Juni 2019 secara offline.

Kebijakan PPDB system zonasi yang tahun 2019 memperoleh reaksi beragam dari masyarakat. Ratusan wali murid siswa dan SMA se-Surabaya mendatangi Gedung Negara Grahadi Surabaya, Rabu (19/6). Mereka memprotes PPDB sistem zonasi dan menuntut agar sistem itu dihentikan. Massa mengatasnamakan dirinya Kompak (Komunitas Orang Tua Peduli Pendidikan Anak SMP se-Surabaya). Seorang calon wali murid, yang juga mewakili massa, Sawitri Nilaswari mengatakan sebagian besar calon wali murid menyesalkan sistem penerapan zonasi itu. Mereka menganggap kebijakan tersebut begitu merugikan anak-anaknya. Kata Nila, mental anak-anak pun down. Perjuangan yang selama tiga tahun dilakukan sekolah, hingga ujian nasional (UN) seakan dihempaskan oleh jarak. "Mereka berpikir, buat apa mereka belajar keras, kalau akhirnya yang diukur adalah jarak,"katanya.

Protes serupa dilakukan para orangtua yang akan mendaftarkan anaknya di SMP di Surabaya. Ratusan wali murid yang belum terima dengan sistem PPDB di Surabaya mendatangi rumah dinas wali kota Surabaya untuk menyampaikan aspirasi karena putra putrinya belum diterima di SMP negeri. 
Aksi sejenis juga dilakukan oleh para orangtua calon siswa di Jakarta, Jawa Barat, dan Jawa Tengah serta Yogyakarta. Pada umumnya pihak yang menolak PPDM system zonasi menilai pemerintah belum siap dari berbagai aspek. Yakni dari ketersediaan jumlah sekolah, sarana prasarana dengan jumlah penduduk usia sekolah dalam suatu wilayah. "Tujuan pemerataan itu baik, tapi yang masih belum siap ini dari berbagai aspek, dari mutu sekolah, sarana prasarana, dan jumlah sekolahnya seimbang tidak dengan jumlah penduduk usia sekolah, itu harus dikaji dulu sebelum membuat kebijakan,"kata Nila.

Menanggapi berbagai protes di masyarakat, pemerintah merevisi Permendikbud Nomor 51 Tahun 2018 tentang Penerimaan Peserta Didik Baru (PPDB). Kuota jalur prestasi yang semula maksimal 5 persen, diubah menjadi 5 sampai 15 persen. 'Kuota untuk siswa yang berprestasi dari luar zonasi yang semula hanya 5 persen, beliau (presiden) berpesan supaya diperlonggar. Karena itu sekarang kita perlonggar dalam bentuk interval, yaitu antara 5 sampai 15 persen," ujar Mendikbud di Jakarta, Jumat (21/6/2019).

Anggota Komisi X DPR RI asal daerah pemilihan Kabupatan/Kota Cirebon dan Kabupaten Indramayu Jawa Barat, Dedi Wahidi, menilai sistem zonasi dalam PPDB belum saatnya diterapkan saat ini. Meski tujuannya baik untuk pemerataan siswa, saat ini penerapan sistem zonasi dinilai masih belum siap. 'Sistem zonasi bisa diterapkan ketika sarana dan prasarana pendidikan sudah tersedia secara merata, mulai dari bangunan sekolah beserta perlengkapannya serta tenaga pengajarnya,"ujar Dedi.

Implementasi kebijakan Permendikbud Nomer 51 tahun 2018 terlalu dini dilaksanakan, meskipun sejatinya system zonasi yang digagas pemerintah sangat berguna dalam melakukan pemerataan pendidikan. "Hanya saja, pemerntah harus mengkaji lebih dalam. Setidaknya butuh waktu 6 bulan dalam sosialisasi sebelum pelaksanaan PPDB agar tidak terjadi gejolak di massyarakat. Termasuk menyiapkan mutu guru, sarana dan prasarana," kata Rektor Universitas Negeri Surabaya, Prof. Nur Hasan. PPDB zonasi seharusnya dilakukan bertahap, misalnya dengan wilayah percontohan. "Apalagi pendidikan di masing-masing daerah berbeda bergantung pada kondisi alam" kata Luthfiyah Nurlaila, guru besar Unesa Surabaya dalam Focus Group Discussion di kampus Unesa Surabaya. ${ }^{22}$

Kesiapan tiap daerah di Jawa Timur untuk menyelenggarakan system zonasi juga berbeda. Di Kabupaten Sampang, pola distribusi SMA/MA dilihat dari supplay dan demand menunjukan bahwa semua lulusan SMP/MTS belum dapat tertampung di

\footnotetext{
22 Atiqoh Hasan, Sistem Zonasi Terlalu Prematur Dilaksanakan, (www.pojokpitu.com tanggal 5 Juli 2019).
} 
SMA/MA. Pemerintah perlu mengkaji ulang mengenai lokasi pembangunan gedung SMA/SMK. Perlu dibangun SMA/MA baru untuk menambah jumlah ruang kelas.

Jumlah guru dan tenaga kependidikan di SMA/SMK di Jatim belum tersebar merata ke sejumlah daerah. Saat ini jumlah guru dan tenaga kependidikan mencapai lebih dari 120 ribu orang. Sementara rasio tenaga pendidik dengan siswa hanya 1:15 untuk SMA dan 1:16 untuk SMK. "Permasalahannya distribusi guru itu yang masih belum benar-benar merata. Khususnya untuk beberapa mata pelajaran tertentu,"kata Kepala Dindik Jatim Dr Saiful Rachman. ${ }^{23}$

Pemerataan tenaga guru menjadi isu krusial tentang penyelenggaraan pendidikan di Jawa Timur. Distribusi guru tidak merata dan jumlah guru masih menumpuk pada satu wilayah. Pada daerah tertentu, tertutama di pedesaan, jumlah guru sangat sedikit. Sebaliknya pada wilayah dengan infrastruktur yang memadai jumlahnya cenderung berlebihan. Ketidakmerataan tenaga pendidik juga terjadi pada kualitas guru, yang terkonsentrasi di perkotaan. Sebagai akibat distribusi guru yang tidak merata pada akhirnya mempengaruhi kualitas pendidikan di Jawa Timur.

${ }^{23}$ Rahmad Santosa, Guru di Jawa Timur Belum Merata, (www.bhirawa.co.id tanggal 24 Oktober 2017).
Kesenjangan rata-rata kualitas lulusan SMA/SMK masih terjadi di Jawa Timur.

Isi tentang kesenjangan kualitas pendidikan juga muncul karena siswa dengan prestasi akademik tinggi menumpuk dalam satu sekolah tertentu (sekolah favorit). Orangtua siswa lebih memilih anakanaknya untuk mengikuti pendidikan di sekolah favorit dengan alasan lebih bermutu dan bergengsi. Sekolah favorit dianggap memberikan jaminan pada kesuksesan kehidupan anak di kemudian hari. Padahal, faktor pendukung kesuksesan seseorang lebih banyak ditentukan oleh dirinya sendiri. Sekolah favorit juga belum menjadi jaminan karena cenderung bertumpu pada input (calon siswa) dan belum melakukan proses pembelajaran yang baik (best process). Paradigma sekolah favorit ini masih menancap kuat di benak masyarakat.

Penerapan system PPDB sistem zonasi, yang mendorong calon siswa dengan prestasi tinggi mengikuti pendidikan pada sekolah yang lebih tersebar berpotensi mengurangi kesenjangan pendidikan. Mereka tidak selalu bisa diterima di sekolah tertentu yang menjadi pilihannya karena faktor zona sekolah yang berbeda. Kebijakan PPDB system zonasi ini secara perlahan akan membuat kualitas pendidikan lebih merata.

Sistem zonasi, menurut Mendikbud Muhadjir Effendy, tidak hanya diperuntukkan untuk PPDB. Namun, untuk 
membenahi delapan standar pendidikan di seluruh wilayah Indonesia. Yakni, kurikulum, sebaran guru, sebaran peserta didik, dan kualitas sarana prasarana. Melalui zonasi, pemerintah dapat lebih mudah menginventarisasi dan memverifikasi kondisi sarana prasarana pendidikan dan kemudian dapat melakukan intervensi yang diperlukan. "Akan kita beri perhatian melalui dana dari pusat, yaitu dana alokasi khusus. Di samping itu, kita juga berharap ada dukungan dana dari APBD (Anggaran Pendapatan dan Belanja Daerah). Kemudian kalau terpaksa, kami akan menurunkan dana dari pusat melalui dana di Kemendikbud,"jelas Mendikbud.

\section{PPDB dan PEMERATAAN SDM BERKUALITAS DI JATIM}

Sejarah menunjukkan bahwa faktor yang paling menentukan keberhasilan suatu bangsa bukan kekayaan alam yang dimilikinya, melainkan kualitas sumber daya manusianya. Negara-negara yang kuat dalam kualitas sumber daya manusianya muncul sebagai negara unggul meskipun mungkin hanya memiliki sumberdaya alam yang sangat terbatas. Indonesia dapat mencontoh Jepang, China atau negara tetangga Singapura dan Malaysia, dalam menyelenggarakan pendidikan bagi penduduknya.

Penyiapan SDM berkualitas secara merata sangat dibutuhkan dalam suasana ketidakpastian dalam ekonomi dunia saat ini. Resesi dan hambatan ekonomi yang dilakukan negara-negara tertentu menuntut kemampuan bangsa Indonesia tidak bisa menyandarkan lagi terhadap sumber daya alam, tetapi pilihan satu-satunya ialah meningkatkan nilai tambah produk-produk industri dengan mendayagunakan keterampilan dan keahlian dalam berbagai bidang. Berdasarkan hal tersebut, maka tantangan bagi bangsa Indonesia ialah meningkatkan nilai tambah dalam rangka meningkatkan produktivitas nasional dan pertumbuhan ekonomi sebagai upaya memelihara dan meningkatkan pembangunan berkelanjutan. Orientasi nilai tambah yang akan meningkatkan keunggulan kompetitif bangsa Indonesia hanya dapat dicapai dengan keunggulan kualitas sumber daya manusia dalam menguasai ilmu pengetahuan dan teknologi yang tepat guna.

Untuk dapat bersaing, Indonesia harus memperbaiki daya saing global. Saat ini Indonesia masih berada di peringkat ke-45 dari 140 negara berdasarkan nilai Indeks Daya Saing 2018 yang dirilis Forum Ekonomi Dunia (WEF). Dari sejumlah indicator, keterampilan pekerja Indonesia berada di peringkat ke-162 dari 140 negara. Sedangkan pasar kerja berada di peringkat ke-82 dari 140 negara. Mengacu pada data Asian Productivity Organization tahun 2017, produktivitas tenaga kerja Indonesia berada di bawah Singapura, Thailand dan Malaysia. 
Dengan rata-rata pertumbuhan sector industri sebesar 5-6 persen per tahun, Indonesia akan membutuhkan sekitar 600 ribu tenaga kerja per tahun. Pemerintah seharusnya meyiapkan pendidikan vokasi, termasuk SMK, untuk menyiapkan SDM terjun ke dunia industri.

Berkaitan dengan kebutuhan tenaga kerja di sektor industri, Jawa Timur juga menghadapi ketersediaan dan kesenjangan SDM berkualitas. Tingkat produktivitas yang rendah, dan kualitas SDM angkatan kerja yang juga relatif rendah, baik dari tingkat pendidikan formal maupun tingkat keterampilan atau kompetensi menjadi tantangan ke depan. Tingkat Pengangguran Terbuka (TPT) di Jatim juga masih tinggi karena pertumbuhan penduduk usia kerja terus meningkat seiring dengan pertumbuhan dan perkembangan angkatan kerja baru, khususnya yang berasal dari lulusan SLTA yang setiap tahunnya mencapai sekitar 480.000 orang.

Berdasarkan proyeksi jumlah penduduk usia kerja (PUK) yang dilakukan oleh Dinas Tenaga Kerja dan Transmigrasi Provinsi Jawa Timur, berdasarkan golongan usia, PUK usia 15-19 tahun akan mengalami penurunan tipis, dari 3.187.031 orang (2019) menjadi 3.176. 377 orang (2020), 3.165.123 orang (2021), 3.153 .592 (2022), dan 3.140 .82 (2023). Namun, jumlah PUK lulusan SMA/SMK dan Perguruan Tinggi akan meningkat. Pada tahun 2019 mencapai
2.709.003 orang menjadi 2.720.993 orang (2020), 2.732.372 orang (2021), 2.745.089 orang (2022) dan 2.757 .865 orang (2023).

Meskipun jumlah PUK usia 15-19 tahun mengalami penurunan, penanganan penduduk kelompok usia ini sangat penting, karena bersamaan dengan usia pendidikan SMA/SMK. Penanganan kelompok usia ini memerlukan kebijakan terpadu pada sectorsektor terkait pendidikan dan ketenagakerjaan. Kebijakan pemerintah dan komitmen dunia usaha sangat dibutuhkan agar dapat menyiapakan mereka menjadi tenaga kerja kompeten, serta agar mereka tidak putus sekolah dan menjadi pekerja anak. Distribusi kualitas SDM juga perlu mendapatkan perhatian agar dapat mendukung pertumbuhan ekonomi suatu wilayah.

Kebijakan PPDB system zonasi yang diberlakukan mulai tahun 2019 setidaknya dapat mendukung proses pemerataan kualitas SDM di Jawa Timur dalam dua hal. Pertama, menjamin ketersediaan SDM dengan kualitas yang setara pada setiap wilayah. Melalui zonasi, semua lembaga pendidikan akan memperoleh input berupa siswa dan melaksanakan proses belajar dengan kualitas yang setara. Tidak lagi terjadi kesenjangan yang tinggi antar skeolah dan wilayah tertentu.

Kedua, system zonasi akan meningkatkan daya saing suatu daerah dalam menarik investasi karena ketersediaan tenaga 
kerja dengan jumlah yang mencukupi dan kualitasnya bisa diandalkan. Pendidikan untuk penduduk usia 15-19 tahun akan tertangani secara merata. Hal ini pada gilirannya akan mendorong pertumbuhan ekonomi dan kesejahteraan masyarakat. Dengan kata lain, PPDB system zonasi akan lebih menjamin pemerataan SDM kualitas di Jawa Timur.

Pemerataan SDM berkualitas selama ini menjadi tantangan di banyak Negara. Indonesia juga mengalami ketimpangan kualitas SDM antara Indonesia Barat dan Indonesia Timur. Isu kualitas SDM di Jawa Timur juga menunjukkan adanya kesenjangan tersebut. Hal ini ditunjukkan dengan Indeks Pembangunan Manusia (IPM) wilayah Tapal Kuda dan kabupaten di Pulau Madura yang rendah. Pada tahun 2018, IPM Kabupaten Bangkalan hanya 62,87, Pamekasan $(65,41)$, Sampang $(61,00)$ dan Sumenep $(65,25)$ atau jauh di bawah Lamongan $(71,97)$ dan Surabaya $(81,74)$.

Rendahnya IPM ini pada akhirnya menjadi salah satu factor penyebab rendahnya pertumbuhan ekonomi suatu wilayah. Selain masalah SDM, faktor penentu utama pertumbuhan ekonomi suatu daerah adalah berhubungan langsung dengan permintaan barang dan jasa dari luar daerah. Pertumbuhan industri yang menggunakan sumber daya lokal, termasuk tenaga kerja dan bahan baku untuk diekspor akan menghasilkan kekayaan daerah dan penciptaan peluang kerja (job creation). Pertumbuhan ekonomi akan lebih memfokuskan pada proses peningkatan produksi barang dan jasa dalam kegiatan ekonomi masyarakat. Pertumbuhan ekonomi juga merupakan salah satu indikator keberhasilan dari suatu proses pembangunan ekonomi.

\section{KESIMPULAN}

Kebijakan zonasi pelaksanaan penerimaaan siswa SMA/SMK merupakan wujud upaya penerapan manajemen pengembangan SDM dalam pengelolaan pendidikan. Kebijakan zonasi ini akan menyebarkan kualitas guru dan tenaga kependidikan ke seluruh wilayah, sehingga output atau lulusan yang berkualitas juga akan tersebar secara merata dalam suatu wilayah.

Pelaksanaan PPDB berbasis zonasi sesuai dengan Permendikbud Nomer 51 tahun 2018 juga akan lebih menjamin penyebaran tenaga kerja dengan kualitas yang hampir sama, sebagai hasil dari proses pelaksanaan pembelajaran dan kualitas siswa yang setara. Ketersediaan SDM dengan kualitas yang setara akan menjadi daya tarik ekonomi karena menghidupkan dunia usaha di daerah secara merata.

Penduduk Usia Kerja pada kelompok usia 15-19 tahun di Jawa Tiimur akan mengalami penurunan tipis, namun jumlah PUK lulusan SMA/SMK dan 
Perguruan Tinggi akan meningkat. Hal ini membutuhkan penanganan secara komprhensif, salah satunya dengan pemerataan kualitas pendidikan melalui PPDB system zonasi. Namun demikian, penerapan kebijakan tersebut perlu dilakukan secara hati-hati dan terencana, agar tidak menimbulkan masalah baru di masyarakat.

Terakhir, penulis menyadari bahwa masih banyak kelemahan dalam penulisan ini, karena hanya memandang dari sisi perencanaan tenaga kerja, sehingga membutuhkan penyempurnaan di sana-sini. Namun yang pasti ini adalah pendapat penulis yang sangat terbuka terhadap saran dan kritikan. Wa allabu a'lam.

\section{DAFTAR PUSTAKA}

Dessler, Garry, Manajemen Sumberdaya Manusia, Edisi ke-14, Penerbit Salemba Empat, Jakarta, 2015

Imron, A, Proses Manajemen Tingkat Satuan Pendidikan. Bumi Aksara, Jakarta, 2014.

Nasihin, S \& Sururi. Manajemen Peserta Didik dalam Riduwan (Ed). Manajemen Pendidikan. Alfabeta, Bandung, 2014. Nasikun, Sistem Sosial Indonesia. PT Raja Grafindo Persada, Jakarta, 2003
Tim Penyusun, Perencanaan Tenaga Kerja Jawa

Timur, Disnakertrans Provinsi Jatim, 2018

Bambang PS Brodjonegoro, Keharusan Transformasi Industri, Harian Kompas, Rabu 3 Juli 2019 halaman 6.

Biyanto, Antara Best Input dan Best Process, Harian Kompas, Jumat 12 Juli 2019 halaman 6.

Waluyo, Eko dan Sulistyono, S.W, Faktor Pendorong Keberangkatan TKI dalam Memenubi Investasi Non Fisik di Kecamatan Selorejo Kabupaten Blitar, Jurnal Inovasi Ekonomi Vol. 03 No.01 Maret 2018 hal : 1-9.

Undang-Undang Nomor 20 Tahun 2003 Tentang Sistem Pendidikan Nasional.

Peraturan Pemerintah Republik Indonesia

Nomor 19 Tahun 2005 tentang Sistem Pendidikan Nasional.

Abdallah, Abdallah. 'Exclusivism and Radicalism in Schools: State Policy and Educational Politics Revisited'. Studia Islamika 23, no. 3 (30 December 2016): 625-32. https://doi.org/10.15408/sdi.v23i3. 4425.

Abudin, Nata. Managemen Pendidikan: Mengatasi Kelemahan Pendidikan di Indonesia. Jakarta: Prenada Media Grup, 2003.

Creswell, John W. Educational Research: Planning, Conducting, and Evaluating 
Quantitative and Qualitative Research. 4th ed. Boston: Pearson, 2012.

- Qualitative Inquiry \& Research Design: Choosing among Five Approaches. 2nd ed. Thousand Oaks: Sage Publications, 2007.

Kristiawan, Muhammad. 'Telaah Revolusi Mental Dan Pendidikan Karakter Dalam Pembentukkan Sumber Daya Manusia Indonesia Yang Pandai Dan Berakhlak Mulia'. Ta'dib 18, no. 1 (2016): 13-25.

Lestari, Sudarsri. 'Analisis Standar Pendidik Dan Tenaga Kependidikan (Studi Di Sdn 3 Tamanagung Banyuwangi)'. Nidhomul Haq: Jurnal Manajemen Pendidikan Islam 3, no. 1 (16 August 2018): https://doi.org/10.31538/ndh.v3i1. 35.

Lexy J, Moloeng. Metodologi penelitian Kualitatif. 29th ed. Bandung: Rosdakarya, 2011.

Maarif, Muhammad Anas. 'Optimalisasi Pembelajaran Pendidikan Islam Di Sekolah/Madrasah Upaya Dan Faktor Penghambat Pembelajaran Pendidikan Islam'. Falasifa: Jurnal Studi Keislaman 8, no. 2 (2018): 273290.

Mawardi, Imam. 'Pendidikan Islam Transdisipliner Dan Sumber Daya Manusia Indonesia'. Jurnal Pendidikan Islam 28, no. 2 (2016): 253-268.
Meldona. Manajemen Sumber Daya Manusia: Perspektif Integratif. Cetakan I. Malang: UIN-Malang Press, 2009.

Miles, Matthew B., A. M. Huberman, and Johnny Saldaña. Qualitative Data Analysis: A Methods Sourcebook. Third edition. Thousand Oaks, Califorinia: SAGE Publications, Inc, 2014.

Nugroho, Puspo. 'Internalization of Tolerance Values in Islamic Education'. Nadwa 12, no. 2 (7 January 2019): 197-228. https://doi.org/10.21580/nw.2018. 12.2.2397.

Patton, Michael Quinn, and Michael Quinn Patton. Qualitative Research and Evaluation Methods. 3 ed. Thousand Oaks, Calif: Sage Publications, 2002. Sugiyono. Metode penelitian pendidikan: (pendekatan kuantitatif, kualitatif dan $\mathrm{R}$ \&D). Bandung: Alfabeta, 2008.

Suharsimi, Arikunto. Metode Penelitian Pendidikan dan Pengembangan. 5th ed. Jakarta: Kencana, 2016.

Tilaar, H.A.R. Perubahan sosial dan pendidikan: pengantar pedagogik transformatif untuk. Indonesia. Jakarta: Rineka Cipta, 2012. Zain, Hefni. 'Pengembangan Pendidikan Islam Multikultural Berbasis Manajemen Sumber Daya Manusia'. Tadris: Jurnal Pendidikan Islam 8, no. 1 (2014): 108-124. 